\title{
Sociomaterial intertwinements in Sami research
}

\author{
The Nordic Museum in Stockholm and the legacy \\ of Ernst Manker
}

Eva SILVÉn

\begin{abstract}
This article summarises a study about Sami related research and collecting at the Nordic Museum in Stockholm, with focus on curator Ernst Manker and the period between 1930 and 1970, however, in a slightly broader time context. Manker was a productive and influential actor in the sociomaterial network that comprised a broad range of people and phenomena connected to Sami issues. His legacy (objects, photographs, exhibitions, scientific research, popular travelogues) is analysed both in its historical context and as a complex contemporary heritage, starting from questions about its possible essentialising or emancipating effects. Although based on an asymmetric power relationship between the Sami and the museum, the research and collections are characterised as culturally intertwined constructions. A postcolonial perspective is used to discuss ways of strengthening the Sami dimension of such heritage: physical transfers (repatriation) and promoting Sami knowledge and meaning related to the collections.
\end{abstract}

Keywords: Sami cultural heritage, Ernst Manker, Nordic Museum Stockholm, actor-network theory, critical/new museology, indigenous knowledge, repatriation, sociomaterial networks, museum collections, museum exhibitions.

This article is based on experiences from a long-term study of the Sami representation at the Nordic Museum in Stockholm. ${ }^{1}$ In 1873 the museum opened to the public as Skandinavisk-etnografiska samlingen (The Scandinavian-Ethnographic Collection). In 1880 it was transformed into a foundation and the name was changed to Nordiska museet (The Nordic Museum). From 1891 the Skansen open-air museum was added to the institution, including a Sami camp. Despite the names, the museum did not have a particular Scandinavian or Nordic profile, instead it took on the role of serving as the main museum of Swedish cultural history. ${ }^{2}$ Ever since its inception, the Sami have been represented in exhibitions, object collections, photographic and other archives as an actual part of what is considered Swedish, but at the same time in a marginalised and exotic position. The museum 
has been an authoritative voice through its selections, categorisations and displays, and the collections reveal the same ambivalent and patronising vacillating between up- and downgrading the Sami as in the general societal discourse. The Nordic Museum is not the only museum to suffer from this historical imbalance, and all over the world efforts have been made to change this, with the help of new kinds of partnerships and new analytical tools for scholarly research.

My aim here is to analyse and discuss the construction of the Sami collections at the Nordic Museum, its historical context and its long-term effects. The empirical focus will be the mid-twentieth century, and in particular the work of ethnographer and curator Ernst Manker. Theoretically and analytically, I have mainly been influenced by new/critical museology, actor-network theory and decolonising/indigenous methodologies, which will be introduced successively. As an employed curator and researcher at the Nordic Museum, I can also situate myself in the subfield "museology from within" (Gustafsson Reinius 2018). I have examined the collections and also been a part of the team behind the exhibition Sápmi - om att vara same $i$ Sverige (Sápmi - on being Sami in Sweden, 2007-) (Silvén 2007, 2009; Westergren \& Silvén 2008). Later, I have carried out the externally funded project Konstruktionen av ett samiskt kulturarv: Ernst Manker och Nordiska museet (The Construction of a Sami Cultural Heritage: Ernst Manker and the Nordic Museum). ${ }^{3}$

\section{Ernst Manker ANd The Nordic MUSEUM}

Ernst Manker (1893-1972) was professionally active during the decades around the Second World War, a period characterised by the growing Sami political movement, forced legislation relating to reindeer husbandry, the building of the welfare state and an expanding modern scholarly research, but also by "scientific", political and ideological concepts such as race biology and eugenics, the discriminatory "Lapps-should-be-lapps policy" and Nazism. ${ }^{4}$ It was also a time when the museums' public role was debated and developed with respect to visitors, education and exhibitions.

The Nordic Museum's long interest in relation to Sami issues peaked with the work of Manker. Educated as an ethnographer, but acting also as an ethnologist, he took up Sami research around 1930. After some assignments at the ethnographic museums in Gothenburg and Stockholm, in 1939 he became curator of the Sami collections at the Nordic Museum, where he created the new "Lapska avdelningen" ("Lapp Department"), with himself as the only member of staff. He carried out contemporary fieldwork as well as historical research, acquired a large amount of artefacts and archival material for the museum, gave lectures, wrote articles, published books in various languages and took thousands of photographs (fig. 1). In the "Lapska arkivet" ("Lappish Archives") he assembled earlier Sami-related documents and images in the museum's collections, along with his own research material and other acquisitions. Moreover, he curated the cultural-historical Lapparna (The Lapps) exhibition, which opened in 1947. Right after, Manker stepped into yet another scholarly field: the emerging archaeological research in northern Sweden, mainly due to the substantial expansion of hydropower plants. He then participated in examinations of Sami settlements, trapping pit systems for wild reindeer hunting, sacrificial sites and human graves (fig. 2). 


\section{Eva SILVÉN}

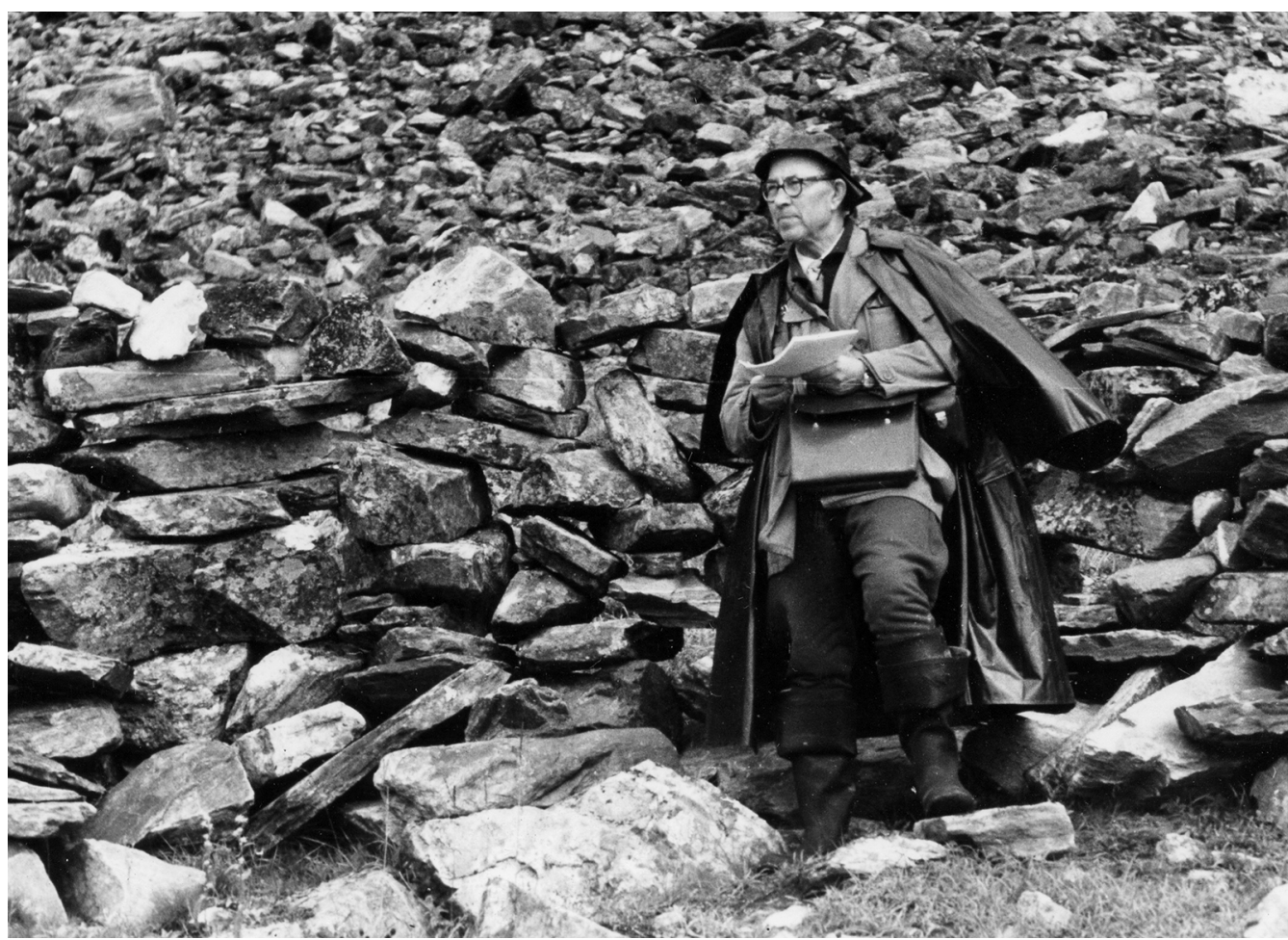

Fig. 1. Ernst Manker during fieldwork, with a camera under his left arm. Liddobakte, Finnmark, Norway, early 1950s. Photo: Ørnulv Vorren, Tromsø University Museum.

Manker retired in 1961 but continued writing for a further ten years and became a well-known researcher of Sami cultural history. Among his many hundreds of publications are, on the one hand, a series of popular travelogues based on narratives and photos from his field tours, and, on the other hand, the scholarly series Acta Lapponica, containing his own as well as other studies. There he published the two parts of his monumental work Die lappische Zaubertrommel (1938, 1950), which contributed to his honorary doctorate in 1953. The material and collections he created, which he sometimes called "a central museum for Lappish culture", form a rich source for the study of Sami culture and history and are - of course - filled with compelling challenges.

"Lappology" was the term for the study of Sami issues at the beginning of the twentieth century, but Manker entered the scholarly field a little too late to be called a "lappologist" (Pulkkinen 2005; Korhonen 2008). Instead he was active during the interregnum between that period and the establishment of modern Sami studies in the 1970s. Although he was considered an authority on Sami issues, he did not work as an "expert" with governmental assignments, as some of the "lappologists" did. Instead, he contributed to the creation of a new research interface between museums and 


\section{SOCIOMATERIAL INTERTWINEMENTS IN SAMI RESEARCH}

universities with a focus on materiality, and his extensive social network included scholars in Sweden, the Nordic countries and elsewhere. $\mathrm{He}$ also collaborated continuously with the Sami, both publicly known activists and artists as well as the principals of the around fifty local reindeer herding communities, siidas, which he enrolled in a "Lappish body of representatives" and connected to the museum (Silvén 2012). Their first task was to answer his questionnaires, but some of them also assisted during his fieldwork, which he, in turn, compensated in different ways.

\section{CONTEMPORARY CONTEXTS AND CONJUNCTIONS}

A crucial starting point for my project was the question of concurrences (or nonconcurrences) in a wider perspective, namely the importance of situating Manker in relation to the contemporary political and ideological climate, or conjuncture. How did his efforts interact with the radical transformations of the time? How did he relate to the growing Sami political movement, to the conflicts between the state and the Sami, to the views of race biology and Nazism, and how did he act during the war? Finally, how did all this affect the results of his research?

In his collecting and research, Manker maintained the museum's earlier focus on past times, although he in fact also documented the contemporary changes. He acknowledged the Sami's right to a modern and comfortable life, but at the same time he could lament the loss of the colourful clothes and the classic reindeer caravans. He supported the Sami political aspirations and contributed on a regular basis to Samefolkets Egen Tidning (The Sami's Own Journal). But he was not an activist, though he could occasionally protest when the authorities

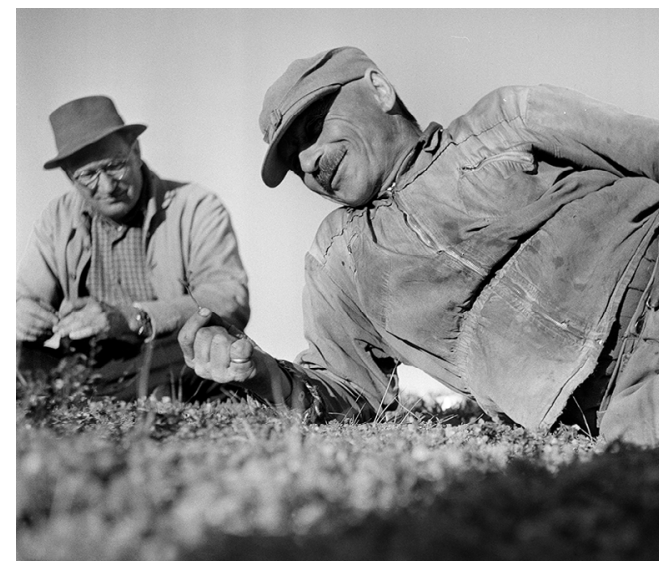

Fig. 2. The Sami Anders Ponga performs a joik during a lunch break, with one of the Swedish researchers listening in the background. From the archaeological excavations of the sacrificial site at Seitesuolo. Råstojaure, Könkämä siida, Kiruna 1950. Photo: Ernst Manker, Nordic Museum.

acted like patrons of the reindeer-herding Sami. Principally, he always backed the Sami, but he also reflected the current discourse and its ambivalence between a structural subordination of the Sami compared to the Swedish majority and a parallel assessment of them as a proud and eminent "race" compared to other minorities and indigenous peoples. In Sweden, race biology was for many decades a mainstream and legitimate "science", and Manker adhered to its way of depicting different peoples in terms of skull forms and "race typical" mental characteristics, even as late as in the 1960s. However, he did not conduct any regular racial research, and he always argued against the most discriminating descriptions. A mutual and close friendship developed between him and many Sami, but he also reserved the right to describe them in the scholar's distanced, paternalistic view.

When in the 1880s the Swedish state decided 
100 that reindeer herding was to be exclusive to the Sami, it also reserved Sami rights for reindeer owners. In the common discourse, "real" Sami were reindeer herders, particularly nomads in the northern mountains. When Sami were represented, the reindeer was usually present - in museums and other media, in research, literature and popular culture, as well as in the Sami self-images. This created a gap between the nomadic reindeer owners and other kinds of Sami - like those living off hunting and fishing, the more stationary forest Sami, Sami settlers, Sami in other professions and those living in other parts of the country (Mörkenstam 1999; Lantto 2004). Early Sami spokespersons in the beginning of the twentieth century, such as Elsa Laula Renberg and Torkel Tomasson, advocated a broader, more ethnic definition of Saminess, but to be accepted as legitimate actors, they also had to adapt to the discourse (Lantto 2000:280-282, passim). Manker certainly knew there were other ways of being Sami, but even for a recognised scholar it was an advantage to focus on the symbolic core of Sami identity. Most of the objects he acquired, and a great deal of his publications, were connected to reindeer herding, and in his exhibition, the long caravan constituted a central element. Thus, in Manker's time, he and other scholars did not - or could not support Sami in other professions and areas being acknowledged as "real" Sami. Another consequence, in our time, is that these people may not find much source material when they want to reconstruct their history. Manker's deep and thorough descriptions of reindeer herding are valid, but they are not the whole truth about the multifaceted Sami life and culture.

During the Second World War, the historically close relation to Germany became a challenge for Swedish scholars due to the politicisation and nazification of science (Garberding 2015). After the war, many people in academia, the business world and leading social positions were exposed as more or less organised German sympathisers and Nazis. Publicly, there are no traces of Manker's opinions, but in some private correspondence he supported Hitler during various stages of the war, although perhaps more as an expression of a strategic and geopolitical anti-bolshevism than an ideological pro-Nazi standpoint. In his work there are no immediate effects, but since he had preferred a victory for Germany, he must have thought Nazi politics possible to reconcile with his own research - even if he might have expected Sweden not to be included in the Third Reich. To some extent, as in other comments in his correspondence, Manker also seems to have practised the kind of mainstream anti-Semitism that for a long time was accepted in many social environments but lost its relative decency after the Holocaust. Anti-Semitism, race biology and the "Lappsshould-be-lapps" policy, all emanated from a set of ideas where the partly synonymous concepts "race", "culture" and "folk characters" represented something substantial and essential, which the scholars should determine and the politicians use in realising their view of purity and order. The idea that such a cultural core, an essence, exists within a people was something Manker shared with many of his contemporaries.

\section{SOCIOMATERIAL INTERTWINEMENTS AND JOINT VENTURES}

During the first half of the twentieth century and outside the Sami society, a large and influential set of people displayed interest in issues related to the Sami. They were researchers, museum curators and collectors, 
artists and writers, politicians, civil servants and other "experts". Together with many Sami, they formed a sphere of interest, focusing on the mountains as nature and the Sami as a people, as well as reindeer husbandry as industry. Individually or in groups, each had their scientific explanation model, political agenda and ideological and artistic driving force. They acted in cooperation as well as in competition and were intertwined in the construction of Sami history and contemporary identity.

I have considered this sphere of interest as the human part of what I have called "the mountains' sociomaterial network", inspired by sociologist Bruno Latour and other actornetwork theorists (e.g. Callon \& Latour 1981/1998; Latour 1992, 1998, 2005). The nonhuman part of the network refers to all the materialities that in various ways contributed to establishing and stabilising the network. Among museums, archives and universities there were objects, images, manuscripts, diaries and letters to fight for, heavy scientific publications to compete with, offprints and dedications as humble proofs of friendship, as well as invitations and congratulations, medals and obituaries serving as high-octane currency. The politicians produced inquiries, laws and regulations, while the Sami created organisations, art, literature, journals and the material culture that was turned into museum collections. In parallel with the human actors, all these materialities served as nodes in the network, with the ability to tighten the fibres and thereby maintain the social relations over time.

The network did not only connect the human and non-human, the material and the immaterial, but also the structural and the individual, as well as the public and the private. Cross-links and intertwinements emerged and cultural borders were bridged, in sparse as well as more dense relationships. Networking was a strategy for Manker; he engaged all kinds of people for his sake, sometimes by pure lobbying. In the publications, academic colleagues received recognition for collaboration during fieldwork, help with reports and laboratory analyses, and, when appropriate, for translation and proofreading. Financiers and publishers also received their well-earned thanks. But above all, Manker addressed the Sami:

Those who have supplied me with the source material for the work, the Lappish informants, they have been so many, that I had to put up a special list. My thanks to them come last at the bottom of the page- but it is felt as the first one (Manker 1968:8).

Manker wrote the agenda, but still it might be possible to talk about joint ventures and joint constructions by Manker and the collaborating Sami. Participating in objectifying yourself, based on someone else's manuscript, is part of the Sami experience, a practice that is shared with other indigenous peoples and ethnic minorities. But, needless to say, without the Sami contribution, nothing would have come out of Manker's ambitions, and every step required negotiations. There were decisions to be made about economic compensation for assistance during fieldwork and excavations, for acting at Skansen, for answering questionnaires and as payment for objects acquired for the collections. There were questions to be solved before taking photographs: should they be allowed at all, how should the image be composed and how should the person depicted be dressed (Silvén 2015)? Collaborative publishing needed agreements about royalties, copyrights and the ownership of the source material. Even if Manker represented a superior cultural authority and the Sami did not always have the last word, 
102 at least they had an exclusive negotiating situation. To compare, early research about the nineteenth century travelling "living exhibitions" often pictured the partaking Sami as victims of the organisers. Instead, archaeologist Cathrine Baglo has uncovered and revealed the Sami's active participation, their agency. The contracts between the actors and the exhibition managers can testify to hard negotiations, and if the agreements were not followed, a strike was the ultimate sanction: "The exhibitors were dependent on the exhibition participants; not the other way around" (Baglo 2011:261).

Consequently, the Samis' role in the mountains' sociomaterial network was more significant than their being informants, photographic objects and guides for Manker and other visitors. Some established themselves as permanent contacts, such as the couple Mattias and Sigga Kuoljok from Sirges siida, in Jokkmokk, Lapland. They became acquainted with Manker during his field trips and later assisted in various ways when he created the Lapparna exhibition (fig. 3). They also worked for other researchers, mainly linguists, and recorded some joiks. Moreover, the whole family, including five children, were among the main characters in the semi-documentary film Från vinterviste till sommarfiall (From Winter Camp to Summer Grazing, 1949), which pictured their seasonal migrations (Kuoljok 2010). Veli-Pekka Lehtola, professor in Sami culture and history, has pointed out that indigenous people often acted as intermediators, or squantos, referring to anthropologist James Clifford's term "the Squanto effect" (Lehtola 2019). Squanto, or Tisquantum, the last survivor of the Patuxet tribe of the indigenous Wampanoag, helped the pilgrims who arrived in Plymouth, Massachusetts in 1620. To their surprise, he

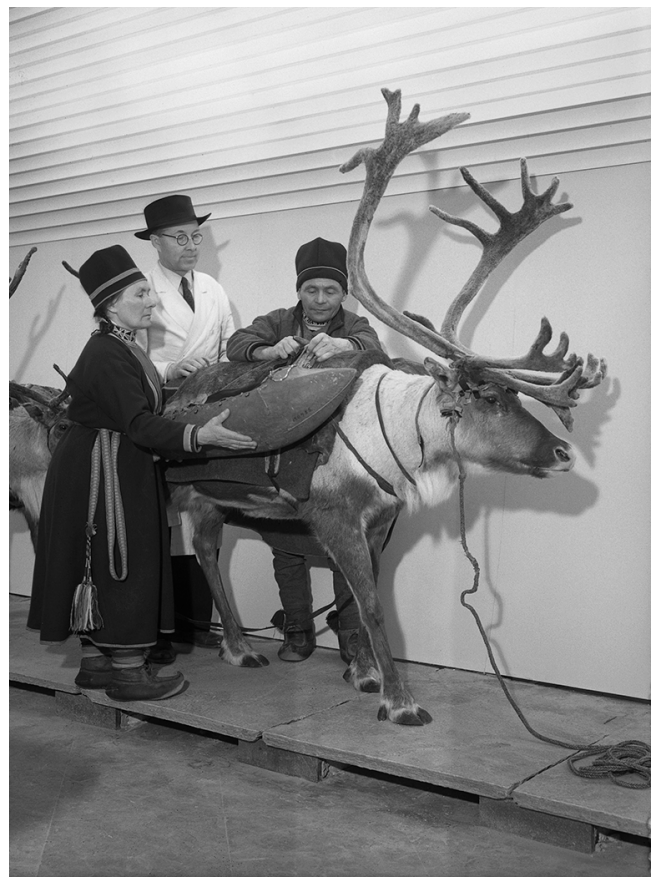

Fig. 3. Among the Sami who collaborated with Manker were Sigga and Mattias Kuoljok, from Sirges siida in Jokkmokk. Here, they are securing the baggage on a stuffed reindeer, accompanied by Manker, for the exhibition Lapparna, 1947. Photo: Lennart Nenkler, Nordic Museum.

spoke English and had just returned from Europe (Clifford 1997b:18). ${ }^{6}$ Lehtola finds "the Squanto phenomenon" quite typical also among the Sami, with individuals wanting to cooperate, and applies the concept in a study of Johan Nuorgam, founder of the Finnish national Sami museum Siida in Inari. All over Sápmi there were culture brokers, like the Kuoljok family and Nuorgam, and many of them became independent interpreters of Sami culture and history, in political, artistic and scientific contexts. Manker collaborated with several of them - including the teacher and activist Karin Stenberg, the photographer 
Nils Thomasson, the artists Nils Nilsson Skum and Anta Pirak, as well as the three editors of Samefolkets Egen Tidning: cultural historian Torkel Tomasson, Sami politician Gustav Park and linguist Israel Ruong (figs. 4-5).

\section{THE MEDIA IS THE MESSAGE}

Manker's main interest was what he saw as the traditional and disappearing Sami culture, material as well as immaterial. When modernisation and mass consumption began to change older Sami ways of life, like many other scholars and curators he wanted to "rescue" as much as possible for the museum, and for contemporary and future research. But he also saw this as a possibility for the Sami to safeguard knowledge about their own history and culture. Moreover, he seems to have had the idea that this was a way to enable development among the Sami and offer them the same possibilities of a comfortable life in modern society as other citizens. By leaving no longer needed artefacts to the museum, the Sami could, he said, with pride build a monument to their traditional culture - and move on, since he saw modernisation as natural, inevitable and righteous. This view gives the museum a potential emancipatory role in societal change, which has not always been recognised.

But did it work that way? Research, documentation, collecting and exhibiting can have both intended and unintended effects on contemporary political and social circumstances. The museums' production of knowledge and cultural heritage related to indigenous groups has often been criticised for creating essentialistic and frozen identities, but at the same time a distinct and documented ethnic character has become an emancipatory tool for many peoples and minorities (Spivak 1985/1996; Smith, L. 2006; Silvén 2014). This

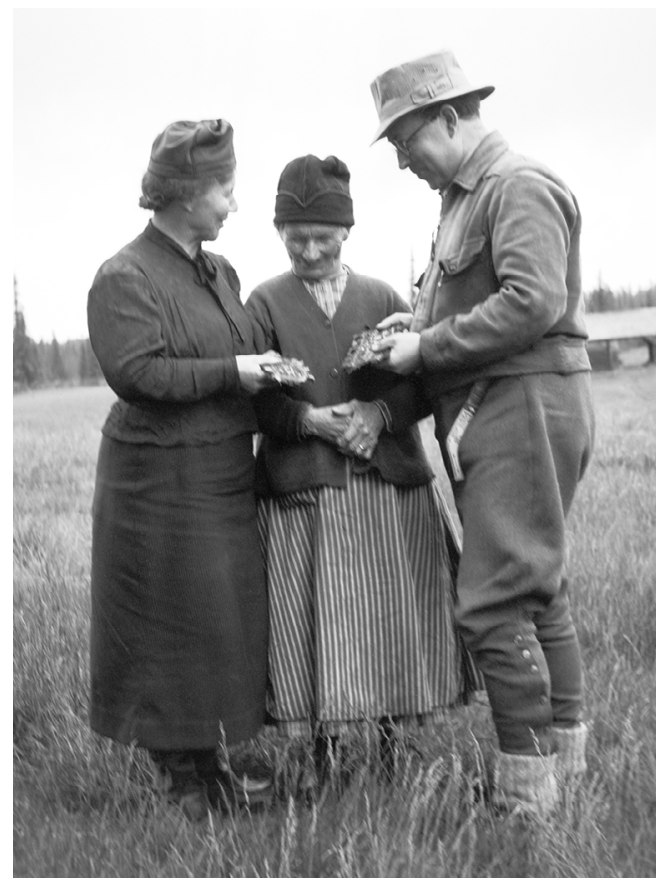

Fig. 4. The Sami teacher and activist Karin Stenberg and Manker are buying an embroidered reindeer bell belt from the maker Cecilia (Sissa) Nilsson. Manker and Stenberg took one piece each of the item, one half ending up in the Nordic Museum, the other in the local history museum in Glommersträsk. Snierra, Mausjaur siida, Arvidsjaur 1938. Photo: Ernst Manker, Nordic Museum.

complex issue formed the background for my research, and initially I raised two main questions regarding the impact of Manker's work: Did the shaping of a "central museum for Lappish culture" - respectfully preserving what was considered cultural heritage and history - help to legitimate Sami emancipation with its aspiration for modern ways of life, change, diversity and the struggle for new rights? Or, did the historical representation lock the notion of the contemporary Sami to an essentialised, homogenous and unambiguous past? 


\section{Eva SILVÉN}

104

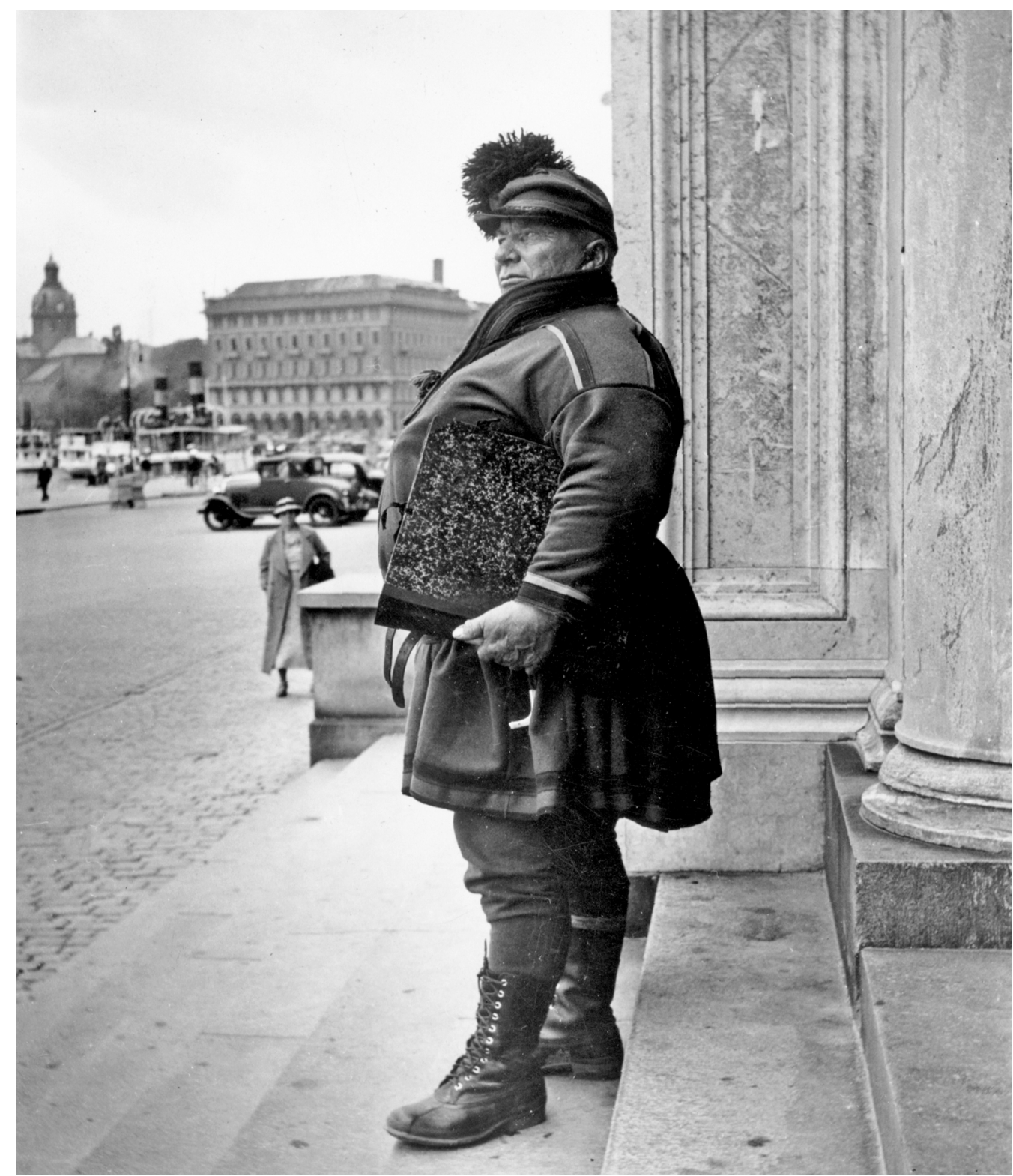

Fig. 5. The Sami artist Nils Nilsson Skum during his first visit to Stockholm in 1936. The portfolio contains the manuscript for his major work Same Sita, published by Manker as Acta Lapponica II, 1938. Skum was a reindeer herder in Swedish Lapland, but in 1909 "he was lured off track", according to Manker, when he at the age of 37 took part in an exhibition tour to Berlin (Manker 1956:50-51). Photo: Ernst Manker, private owner. 
What could then be the methods for measuring and judging the effects of Manker's work in that way, in his own time and after, or, for determining the societal impact of Sami research more generally? One way could be to closely examine the historical material itself, analysing how the various categories were constructed and comparing their assumed effects. Following the Latourian line of thought, the museum collections could thus be viewed as actors in the mountains' sociomaterial network, with the power to create and maintain social relations, conceptions and identities (e.g. Callon \& Latour 1981/1998; Latour 1992, 1998). Accordingly, my research has led to different answers to the two main questions, depending on the type of media.

The aforementioned Lapparna exhibition showed what had become history already at its opening in 1947, and during the more than thirty years it was on display, the distance to contemporary Sami life increased. But simultaneously the (imagined) border between past and present must have been blurred since certain elements in Sami culture had survived in partly similar forms, such as the dress, some handicrafts and the reindeer herding. Moreover, Manker had chosen to write the exhibit texts mainly in the present tense (except the parts about traditional religion), which has been considered a classic anthropological/ ethnographic method for subordination. Thus, the Sami were situated in the timeless vacuum that anthropologist Johannes Fabian has termed the ethnographic present, and were exposed to the denial of coevalness, meaning that their ways of life were not regarded as concurrent with the mainstream Swedish society (Fabian 1983/2002:31, 80, passim). The adjacent photo from 1954 visualises this dilemma, when a group of Sami students happened to mirror themselves in the

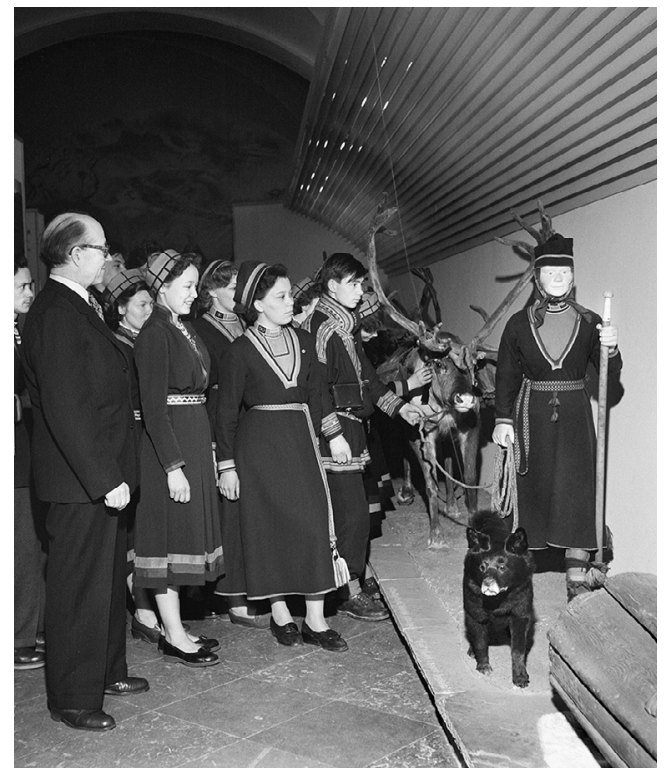

Fig. 6. Ernst Manker guiding a group of students from the Sami Folk High School in Jokkmokk through the exhibition Lapparna, 1954. Photo: Nordic Museum.

exhibition's mannequins (fig. 6). The visitors used the traditional costume as honorary dress on certain occasions, but not yet as an emancipatory tool as in the later ethnopolitical movement. Consequently, one effect of the exhibition was to associate contemporary Sami with historical living conditions.

The collections of Sami material culture, the artefacts, in the Nordic Museum also had - and still have - an emphasis on past times and do not reflect the radical changes in living conditions during the twentieth century. ${ }^{7}$ The new commodities that were introduced among the Sami were not regarded as suitable for acquisition, for example lumber jackets, wellies, overalls, cotton shirts and dresses, sun glasses, binoculars, baby pacifiers, alarm clocks and sewing machines. What we today 
106 call contemporary collecting was not an issue, but that was not the single reason for omitting them. Only things that were considered specifically Sami were supposed to be included in a Sami collection, a restriction that had been applied to earlier collecting as well. Therefore, in the Sami collections of the Nordic Museum there are a few razors, eyeglasses and one mirror, but no watches, combs, towels, soap cases or crockery, although such items were also in use among the nomadising Sami. As in other museums with comparable collections, both acquisitions and exhibitions were strictly edited to an ideal-typical selection, a canon, in accordance with an idea of a Sami essence. ${ }^{8}$ Consequently, judged from the material representations, the Sami appear as radically different from other citizens, entirely defined by their unique ethnic character, which in turn was delimited to traditional and "uncivilised" expressions, in contrast to mainstream modernisation, emancipation and change.

Still, there is a third category of representations - photography. Manker was a wellknown and respected photographer and many of his pictures of the more traditional Sami ways of life have been used in various contexts, with some of them turning into veritable icons. But there are exceptions that open a crack in the historicising image of the Sami. Among Manker's photographs from his many field trips, from the late 1920s to the late 1950s, are pictures that show the contemporary use of the new types of clothing, household utensils, motor vehicles and other kinds of material culture - just the type of objects that were not acquired for the museum collections. However, Manker included these photographs in his popular travelogues, which he published on average every third year during his career. They were widely disseminated among the public, and must have challenged the other frozen conceptions of the Sami. The narrative was often about the break between old and new, between tradition and modernity, and the photographs visualised, for example, the hybrid mix of modern sports jackets and peaked caps together with older parts of the traditional dress (fig. 7). Obviously, Manker was aware of the discrepancy between contemporary Sami life and the museum representations, which he explicitly commented on in one of his late books: "While the old cultural forms thus survived in the halls of the museum, on the outside modern life found new ways and means to carry on - to exist" (Manker 1970:151).

\section{Changing power relations}

Despite an at many times friendly cooperation, there was a fundamental imbalance in the power relations between the Sami and the researchers. There was a friction that gradually changed, but it was not until the 1970s and 1980 s that a more radical shift occurred. Then, the foundation for today's situation was created through a growing Sami political activism, the strengthening of the regional museums and the establishment of new universities and colleges in Sápmi - which meant that new institutions entered the network and challenged those that had earlier held the leading positions. Increasing cooperation across the national borders also contributed to transforming the former periphery into a new centre. The "nation" Sápmi developed into a node in a new global network of indigenous peoples alongside other transnational identity building projects around the North Calotte and the Barents region. As a result, the current power structure in Sami research was explicitly questioned.

Manker died in 1972, just after his 79th birthday. However, a brief glance at the 


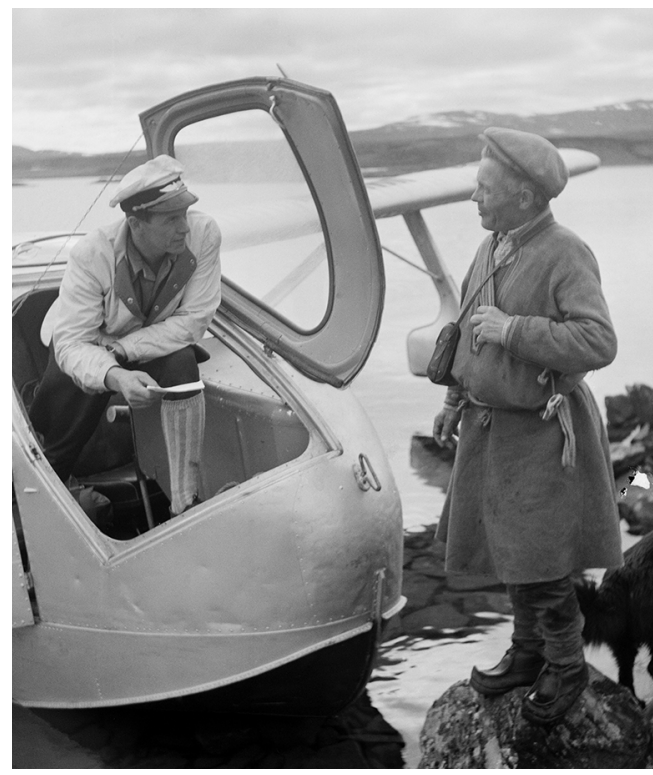

Fig. 7. "Down from the clouds came AB Lapplandsflyg's 'Seabee' - the mountains' modern messenger and a popular craft" (Manker 1958:136). The pilot Knut Hedström had transported a couple of reindeer herders and their dogs to Mattias Kuoljok's summer camp at Lake Pårrojaure. Kuoljok himself with a modern cap added to his traditional dress, and with the binoculars at hand. Padjelanta, Sirges siida, Jokkmokk 1954. Photo: Ernst Manker, Nordic Museum.

subsequent relations between the Sami and the Nordic Museum will shed some further light on his time in a comparative perspective. In November 1973, a conference on Sami research was held, one in a series of anniversary symposia on the occasion of the museum's centennial (Kjellström 1974). Among the participants were a few Sami, one of them Ole Henrik Magga from Norway, who later became a prominent Sami politician and researcher. At that time he worked at Tromsø Museum, and in his presentation he emphasised the ambition to involve Sami academics in the museum's research. Swedish experiences from Norway when she gave an account of an interview with the then young student Johan Klemet Kalstad, later professor at Sami University of Applied Sciences (Sámi Allaskuvla/Samisk Høgskole) in Kautokeino. Under the headline "Are the researchers a real nuisance in Sami areas?", Kalstad had heavily criticised research in Sami areas by nonSami academics. The following year, 1974, at a conference in Tromsø, the museum curator and scholar Alf Isak Keskitalo gave his famous speech "Research as an inter-ethnic relation", where he repeated and developed the same criticism as Kalstad and provided a list of requirements for counteracting the asymmetry in Sami research (Keskitalo 1994). ${ }^{9}$

This new, expanding scholarly conjuncture was handled in different ways by different parties. At Tromsø Museum, the exhibition Samekulturen (The Sami Culture) opened in 1973, with the artists Idar Ingebrigtsen and Iver Jåks among the participating Sami (Fonneland 2019). But what became self-evident in Troms proved to be more difficult in Stockholm. A few years later, the Nordic Museum decided to replace Manker's Sami exhibition. A project group was established, led by the ethnographer Rolf Kjellström, Manker's second successor. The new exhibition - Samer (The Sami) - was to have its grand opening on 24 October 1980, and a month before this the exhibition texts were sent to the Swedish Sami Association (Sámiid Riikkasearvi/Svenska Samernas Riksförbund, SSR) for information. The response was so negative that the opening was postponed. SSR appointed a working group, which recommended changes in texts, maps and displays in two comprehensive memos, and almost a decade of conflict had started.

Since the exhibition was very detailed, 
108 many of the remarks referred to facts, terms and wordings, but the Sami also wanted the exhibition to speak explicitly about the problems caused by extractive industries and the ongoing struggle for equal rights. Another crucial issue was the opening scene. The museum had arranged a tableau showing an encounter between a bear and a male Sami mannequin, dressed in a reindeer fur coat and with a spear in hand. The SSR opposed this image, arguing that it might strengthen false conceptions about the Sami wanting to extinguish wild species. It was not until the last month before the opening that it was replaced by another male mannequin in a traditional North Sami dress, lasso in hand and in front of a huge photo of a reindeer herd in a mountain landscape. In a time when official definitions of Saminess and ingrained stereotypes were questioned anew, the display should have been problematic, but in the current situation it could obviously work as a unifying representation.

However, the main problem seems to have been the Nordic Museum's attitude towards the Sami. The conflict went public at the opening event, 26 March 1981, when the chairman of SSR, Nikolaus Stenberg, gave a critical inaugural speech, that was published shortly after in the journal Samefolket (The Sami People), together with an interview with a member of the Sami working group and a comment from Lars Thomasson, influential Sami politician and researcher. All criticised the Nordic Museum for its lack of respect and sensitivity towards Sami views and values and how the Sami had been treated. Thomasson concluded:

The Sami Department at the Nordic Museum has in one way a key position regarding information about the Sami. The museum can now either enable a real and active Sami participation in that information, or leave the Sami to their previous, passive role when, essentially, others speak about them and their culture. The choice should not be difficult in 1981. And still, it's not too late, even though it's at the twelfth hour (Thomasson 1981).

The whole 1981 volume of Samefolket witnesses a year with several important political issues on the agenda - like Skattefällsmålet in Sweden (the Taxed Mountain Case, when the Sami lost a fight against the Crown regarding land ownership) and the Alta conflict in Norway (about the building of a hydropower plant across the Alta river) - in addition to the growing international indigenous context, with the formation of the Working Group on Indigenous Populations (WGIP), later the United Nations Permanent Forum on Indigenous Issues (UNPFII). Sami cultural politics and Sami cultural heritage were also highly topical, and demands were made for Sami national museums in all the countries concerned. In this political climate it was no longer enough for the Nordic Museum and other mainstream museums to offer the Sami involvement and influence - what was at stake was a major shift of authority. However, the Nordic Museum did not manage to cope with this new situation, and in 1989 it finally lost its earlier leading role when Ájtte, the Swedish Mountain and Sami Museum in Jokkmokk, was inaugurated and became the main Swedish museum for Sami history and culture. The purpose was to constitute a Sami voice and present Sami perspectives, in line with Kalstad's and Keskitalo's arguments. In connection with the opening, and as a proper repatriation, the Museum of Ethnography in Stockholm decided to transfer its Sami object collection to Ájtte, comprising about 500 items (Kåks 2000). The transaction was both a literal and a symbolic act, which not only added a 
new actor to the mountains' sociomaterial network, but also re-contextualised the objects. Instead of being elements of an ethnographic museum in the capital, they became actors in a national museum of Sami culture, located in the historical Sami core area.

\section{Sami and Swedish: Place and POSSESSION}

But what kind of material was sent back to Sápmi from the Museum of Ethnography - or still remains in the storerooms of the Nordic and other mainstream museums? Questions have been asked about whether these and other collections really should be regarded as Sami cultural heritage, or rather, if they are parts of a Swedish cultural behaviour that includes collecting and visualising Sami life, culture and history. ${ }^{10}$ I would like to answer both depending on where the focus is. Firstly, the objects themselves are of Sami origin, defined as made, owned or used by Sami people. Secondly, the collections are obviously joint constructions - however unequal - and testify to intertwined influences from several types of actors and networks. Thirdly, the identity of an object is something shaped by varying practices; "Sami" or "Swedish" is not an unambiguous and stable quality, but a created relationship or interface that can change over time and in different contexts - not too different from a human being's cultural or ethnic identity. The artefacts that were brought to the museums from Sami environments, whether they were in use or tucked away to be burned, were given a partly new identity; with the help of denomination, classification and date of acquisition they were incorporated into the systematic context of the museum's catalogue and labelled with the museum's inventory number. However, this new identity did not exclude the former history; on the contrary, 109 museums have mostly been keen to keep a record of the provenance of their collections, and even further movements and transactions are neatly documented. Therefore, it is often possible to follow, or "shadow", these objects, as economist Barbara Czarniawska puts it, and uncover their "cultural biography", according to anthropologist Igor Kopytoff (Kopytoff 1986; Czarniawska 2007:91, 106). Both concepts can be seamlessly connected to the idea of physical artefacts as actors in sociomaterial networks, together with the narrative aspect, insofar as the methodology creates stories around the objects that intertwine time, space and different sociocultural environments. Hence, these methods make it possible not only to disclose the cultural effects of a shift of location and belonging, but also help to determine who may be the rightful recipient in a reversed process, a repatriation.

I will present here two examples, both relating to Manker and the Nordic Museum, and which in a long-time perspective show what such changes can do to the identity of an artefact. ${ }^{11}$ The first case is a sieidi, a sacred object, from Sieberbuollda in Sirges siida, Jokkmokk. It was originally abducted by two young noblemen during a mountain trip in 1900. After lengthy negotiations, the Sami guides eventually helped them carry the sieidi away, which a few years later was donated to the Museum of Ethnography. In 1947, Manker borrowed the sieidi for the Lapparna exhibition, and it was also on display in the following Samer exhibition, in both cases representing the historical Sami religion and the notion of sacred places and objects (fig. 8). In 2002, after repeated pressure, it was finally returned to the Museum of Ethnography and deposited at Ájtte Museum, along with the already transferred collections. At Ájtte, the 


\section{Eva SILVÉN}

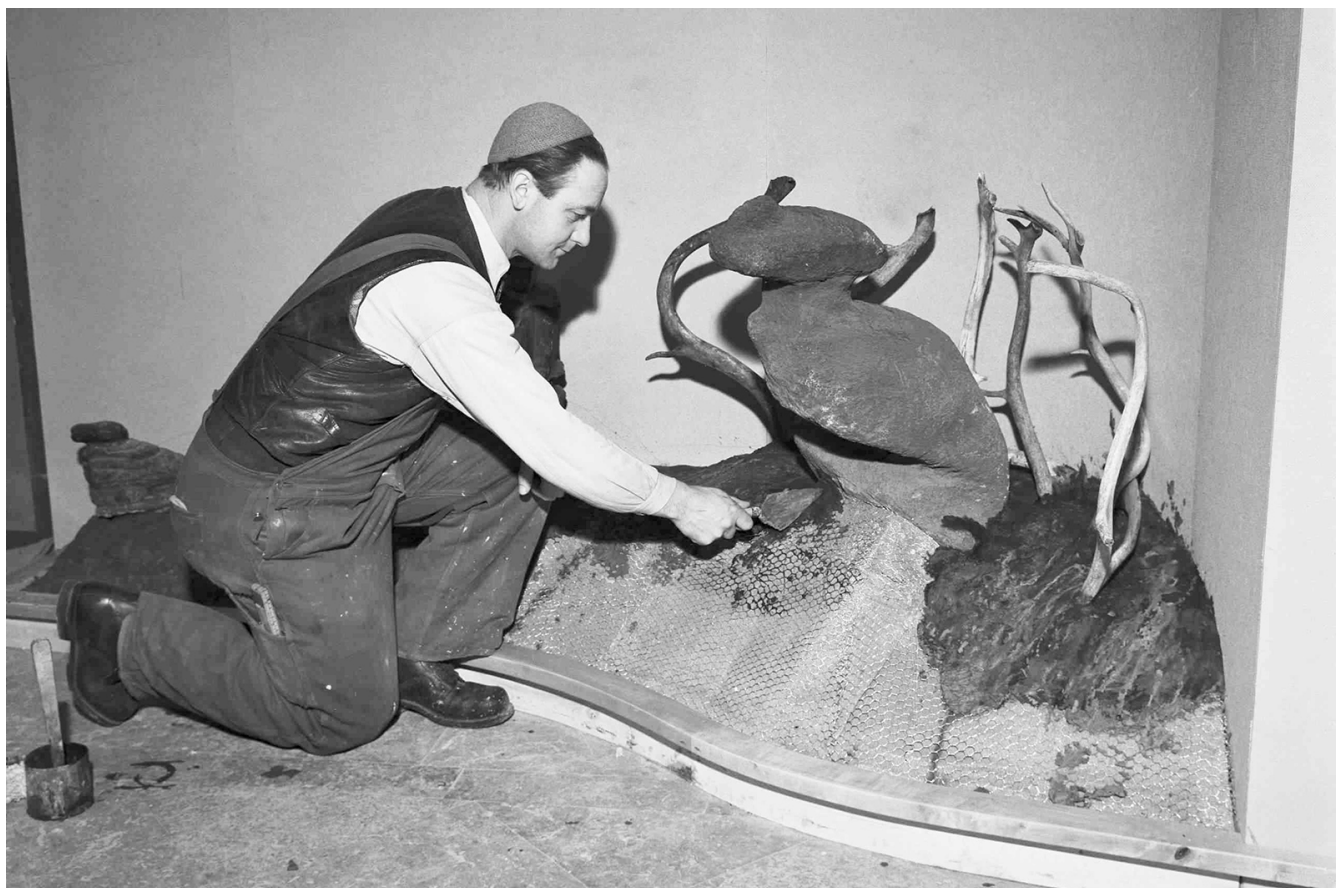

Fig. 8. Modeler Sigvard Hedblom, installing the sieidi from Sieberbuollda in the Lapparna exhibition, 1947. Photo: Olof Ekberg, Nordic Museum.

sieidi was once again put in an exhibition on Sami religion, but this time along with its biography and a detailed description of its abduction from the mountain. The source was a recently found and now displayed diary kept by one of the noblemen. In addition to being a sacred object, now the sieidi was also evidence of the circulation of Sami material and spiritual culture as a dimension of Sami history.

The second case is the so-called Shadow Man, Soejvengelle, in the South Sami language, buried in Vapsten siida, southern Lapland. In 1950 Manker and his colleagues excavated the grave and brought the remains with them to Stockholm for further examination in exchange for a written promise that they would be returned. Through this transaction, the bones were turned into scientific research material and remained so for the following fifty years when they were kept in the Nordic Museum, the Osteoarchaeological Research Laboratory at Stockholm University and the Swedish History Museum, in turn. It was not until the local Sami association had requested a return of the remains that a re-burial was performed, in 2001, and then once again Soejvengelle became a Sami ancestor, in his physical and narrative home environment however, according to the osteological analysis, three hundred years older than in the local oral tradition.

By following these and other artefacts over the years, it is possible to see how the identities "Sami" and "Swedish" have been geared up 
and down in relation to the physical transfers between different hands. Every individual or institution along the way can claim to be part of the object's cultural biography, and it is therefore no wonder that the issue of repatriation can cause conflicts between peoples, as well as nations. Film and media scholar Mark B. Sandberg has stated that the presence of an artefact in a museum is always testimony of a relocation. Ethnographic (and ethnological) objects bear traces of being displaced and it is obvious that they have had a home elsewhere and continue to evoke that context (Sandberg 2003:182-183). This is a question of an inherent paradox, they are both here and there at the same time - just like the sieidi from Sieberbuollda, Soejvengelle's remains are both Sami and Swedish heritage, simultaneously. I find this perfectly illustrated by philosopher Ludwig Wittgenstein's DuckRabbit optical illusion: the object is the same, but by fixing our gaze we can choose to see either identity, reinforced by the physical location and the institutional affiliation (fig. 9).

\section{SAMI AND SWEDISH: KNOWLEDGE AND MEANING}

To contest the cultural identity of objects and collections, the physical decolonisation - repatriation - has its theoretical equivalent in scholarly discourses, such as postcolonial/ decolonising studies, indigenous methodology and new/critical museology. ${ }^{12}$ Here, the museums have been examined as societal institutions with particular focus on their production of knowledge and meaning, based on object collections, archives and exhibitions. Thus, as shown above, the Sami (like other indigenous groups or minorities) have been characterised by certain conceptions connecting them to social positions and cultural expectations,

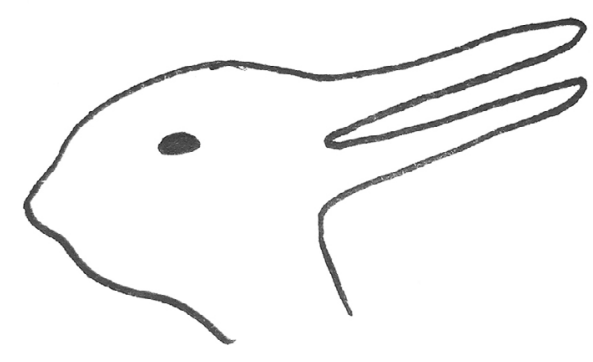

Fig. 9. The Duck-Rabbit. Author's drawing.

different from other citizens. Referring to actor-network theory, such conceptions about ethnic identity can be considered as black boxes, a useful analytical tool for "truths" that have been taken for granted and not questioned, created by a series of interconnections between human and material actors (Callon \& Latour 1981/1998:19-20).

However, what has been packed may under other circumstances be unpacked, and reorganised. Many museums have tried to rewind the process and explore how the "packing" was done, aiming at detecting the mechanisms of subordination and finding other forms of knowledge and meaning in the collections, including indigenous views. Among the many projects on this theme are the edited volumes Unpacking the Collection. Networks of Material and Social Agency in the Museum (Byrne et al. 2011) and the sequel Reassembling the Collection. Ethnographic Museums and Indigenous Agency (Harrison, Byrne \& Clarke 2013). Both titles and subtitles can be read as keywords for the field and issues at hand. My way of contributing to this discourse, as an ethnic (non-Sami) outsider but a museum insider, has been to scrutinise the legacy of Manker - in fact an authoritative black box that nobody has tried to open before. 
112 At the Nordic Museum, a first step was taken in the making of the Sápmi exhibition, which opened in 2007. At that time, we curators decided not to present a classic culturehistorical account as in earlier exhibitions. Instead, we wanted to build the display around five themes influenced by postcolonial and critical museological research. ${ }^{13}$ To manage this, it was necessary to examine and focus on the collections in a new way in order to find the hidden Rabbits instead of the obvious Ducks (or the other way around), and to reassemble them according to our storyline. For this purpose, a Sami focus group was established, selected by seven organisations and institutions. Together we explored the collections in search of traces that could enlighten the objects' historical and contemporary cultural significance from a Sami point of view. ${ }^{14}$

During the last twenty years, the concept contact zone has been frequently applied on this type of collaborative interface between museums and indigenous peoples. On the one hand, it has been embraced as a postcolonial emancipatory key, on the other hand, it has been criticised as a neocolonial embellishment of a fundamentally asymmetric relationship (Pratt 1991, 1992/2009; Clifford 1997a; Boast 2011). For Manker as well, the museum obviously was a kind of contact zone, where Sami ethnicity was defined and negotiated in cooperation as well as in friction and sometimes but seldom - even in conflict with those involved. However, the main difference between earlier partnerships and those formed later is the current ambition (although perhaps not always the result) to share authority and move the interpretative prerogative from the museums to the source communities. In Manker's time, the asymmetry between the two parties was part of the black box and not questioned, in contrast to the situation around the 1981 exhibition, when the box was unsealed and the deep conflict arose.

When the new Sami museums that opened in the late twentieth century created exhibitions about Sami cultural history they used the existent "typical" and "authentic" museum objects and collections, sometimes returned from mainstream museums. Early critical scholars believed that they, like other indigenous museums, tended to repeat essentialising and stereotypical images from the mainstream museums, once again staging timeless presentations with the usual focus on reindeer herding (cf. Olsen 2000). Later research has disputed this criticism, asserting that what were perceived as stereotypes took on another meaning in the new context (Mathisen, S.R. 2004; Mathisen, S.O. 2010; Lien \& Nielssen 2012). The timelessness should not be equated to the colonial ethnographic present, rather to Sami and other indigenous views of time, with history more intertwined with contemporaneity. Instead of critical interpretations like auto-exoticism and selforientalism, concepts like strategic essentialism and reappropriation of indigenous images were introduced in the scholarly analyses (Spivak 1985/1996; Sissons 2005:9). Since minority and indigenous policies require a distinct individuality with specific and acknowledged characteristics, even time-worn representations could be used for emancipatory purposes. The symbols are maintained but charged with new knowledge and alternative meaning - turning the Ducks into Rabbits - which makes the potential contradiction between essentialism and emancipation less distinct and more ambiguous. But still, the intended "strategic" essentialism can end up as pure essentialism if the mainstream interpretation manages to dominate over the indigenous one, and if cultural continuity and re-appropriation are 
understood as simple repetition. ${ }^{15}$ Therefore, many Sami artists and artisans today claim the right to develop traditional forms of handicraft, dress, food and joiking, in order to preserve Sami cultural heritage, knowledge and meaning. For them, the "authentic" lies in the creator's understanding of the tradition, the environment and the materials, as well as in the ability to express one's own vision of Sami culture, not in copying older forms (Durand 2010:105, passim). Thus, together with critical museology, indigenous methodology and contemporary collecting, artistic interventions offer methods for questioning the narrow and conventional selection that in general characterises historical Sami collections in mainstream museums.

\section{From AUTHORITY TO ANTIQUITY}

In this article I have analysed and discussed some aspects of Ernst Manker's and the Nordic Museum's representations of Sami history and culture in their contemporary political and scholarly context. I have also touched upon their long-term effects and possibilities. Museums have been significant platforms for constructions of Sami identity and cultural heritage, first for outsiders like the "lappologists" and their successors, then for the late twentieth century's Sami ethnopolitical movement. Today, indigenous heritage is in motion more than ever, and earlier notions regarding place, possession, knowledge and meaning are being challenged.

At some point, Sverker Sörlin, historian of ideas, reflected over how quickly Manker turned from "authority" to "antiquity" after his death in 1972. As we have seen, this was at the beginning of the period when Sami scholars started to demand control over research in Sami areas and also to express the desire to conduct research themselves, instead of mainly being informants or guides. It was also a time when postcolonial perspectives were introduced in ethnography, ethnology and social anthropology, which changed earlier ways of describing and interacting with indigenous peoples. Furthermore, the highly ranked positivist object research became obsolete, and consequently interest in Manker's and other collections that it was connected to decreased. However, soon the constructivist views of new/critical museology, together with perspectives from indigenous methodology, once again made these collections worth studying.

As shown above, particular parts of Manker's work - objects, photographs, travelogues and the exhibition - probably had different effects in their time, and can have different significance for us today. This means that it might not be possible to answer the questions I asked at the beginning of my project as unambiguously as I phrased them then: Can Manker's efforts be said to have contributed to a forward-looking Sami emancipation or a backward-looking essentialisation? Now on this point I would like to answer: Probably both, in a mutually dynamic and productive friction.

\section{Notes}

1. For the history of the Nordic Museum, see e.g. Medelius, Nyström \& Stavenow-Hidemark 1998.

2. The contemporary union between Sweden and Norway (ended in 1905) was mirrored at Skansen by the building Vastveitloftet from Telemark, while thousands of objects of Norwegian origin - including Norwegian Sami - were added to the Nordic Museum's collections.

3. Financed by Riksbankens Jubileumsfond (The Swedish Foundation for Humanities and Social Sciences) 2009-2011. Continuous results have 


\section{Eva SILVÉN}

114 been published in Silvén 2010, 2012, 2014, 2015, 2016, concluded in Silvén 2020.

4. According to the "Lapp skall vara lapp" policy, the Sami were seen as an inferior race, which was taken as justification for attempts to keep them outside the modern society. They were allowed to carry on with the traditional nomad reindeer herding, but otherwise protected from contemporary life, which they were not considered able to cope with. Lantto 2000:40-42, passim; Lundmark 2002:63-75.

5. Among other contemporary researchers in Sami history and culture, more or less considered "lappologists", were K.B. Wiklund and Björn Collinder in Sweden, J.K. Qvigstad, Konrad Nielsen, Asbjørn Nesheim, Knut Bergsland, Ørnulv Vorren and Gutorm Gjessing in Norway, Väinö Tanner, Karl Nickul and T.I. Itkonen in Finland.

6. Cf. how Sami gained experiences from abroad while travelling around with the "living exhibitions". Baglo 2011.

7. Fully 40 per cent of the total collection of over 6,000 single items was accessed before the year 1900 , around 35 per cent $1900-1950$, and 15 per cent after 1950. Hammarlund-Larsson 2008:87.

8. The same rationale applied to the collecting of Sami immaterial culture and folklore, cf. Mathisen, S.R. 2000.

9. See Junka-Aikio 2019, for this "Samification of research", its further development and consequences.

10. Recently actualised in the research project Sami audio-visual collection - films and television programs in archives and on the web, carried out by the Royal Library et al., financed by the Swedish Research Council 2019-2021.

11. See Silvén 2016 for a more extensive version of the two cases plus a section about Sami shaman drums, all with detailed references.

12. Among the many titles used for my project are Karp \& Lavine 1991; Smith, L.T. 1999/2006; Peers
\& Brown 2003; Bennett 2004; Porsanger 2004; Sleeper-Smith 2009; Xantaki et al. 2017; Lehtola 2018.

13. The initial themes were: Origin, on history, kinship, perceptions of identity and ethnicity; Justice and injustice, on land rights, legal processes and political movements; Brought "home" returned "home", focusing on the museum's material collections; Whose view, whose voice, whose story, with documents and images from the archives; The third space, on cultural encounters and hybrid identities from a postcolonial perspective. Silvén 2007.

14. The work was monitored and analysed by doctoral student and social anthropologist Carine Durand, see Durand 2010.

15. See the recap of the debate on strategic essentialism in Durand 2010:18-21.

\section{REFERENCES}

All data and references regarding Manker and the Nordic Museum that are not accounted for in this text are to be found in my other publications on this topic. All translations are mine.

\section{Archival sources}

Nordic Museum, Stockholm:

- Ämbetsarkivet / Official Archives: Exhibitions, Sami exhibition 1981

- "Lapska arkivet" / "Lappish archives"

- Ernst Manker’s archives

\section{Literature}

Baglo, Cathrine 2011. På ville veger? Levende utstillinger av samer i Europa og Amerika. Tromsø: Tromsø University.

Bennett, Tony 2004. Pasts Beyond Memory. Evolution, Museums, Colonialism. London: Routledge.

Boast, Robin 2011. "Neocolonial collaboration. Museum as contact zone revisited." Museum Anthropology 1, 56-70. 
Byrne, Sarah, Anne Clarke, Rodney Harrison \& Robin Torrence (eds.) 2011. Unpacking the Collection. Networks of Material and Social Agency in the Museum. New York, NY: Springer.

Callon, Michel \& Bruno Latour 1981/1998. “Den stora Leviatan isärskruvad. Hur aktörer makrostrukturerar verkligheten och hur sociologer hjälper dem att göra det." In Artefaktens àterkomst. Ett möte mellan organisationsteori och tingens sociologi. Stockholm: Nerenius \& Santérus, 11-39.

Clifford, James 1997a. "Museums as contact zones." In James Clifford: Routes. Travel and Translation in the Late Twentieth Century. Cambridge, MA: Harvard University Press, 188-219.

Clifford, James 1997b. “Traveling cultures.” In James Clifford: Routes. Travel and Translation in the Late Twentieth Century. Cambridge, MA: Harvard University Press, 17-46.

Czarniawska, Barbara 2007. Shadowing and Other Techniques for Doing Fieldwork in Modern Societies. Malmö: Liber.

Durand, Carine 2010. Anthropology in a Glass Case. Indigeneity, Collaboration, and Artistic Practice in Museums. Saarbrücken: VDM.

Fabian, Johannes 1983/2002. Time and the Other. How Anthropology Makes its Object. New York: Columbia University Press.

Fonneland, Trude 2019. “The Samekulturen exhibition. A social actor at the Tromsø University Museum. Knowledge production and shifting circumstances." Nordisk Museologi 3, 118-133.

Garberding, Petra 2015. Vetenskap mellan diktatur och demokrati. Svensk och tysk folklivsforskning i skuggan av nazismen och kalla kriget. Malmö: Universus Academic Press.

Gustafsson Reinius, Lotten 2018. "Museology from within. Thinking critically through and with museums." Nordisk Museologi 1, 150-153.

Hammarlund-Larsson, Cecilia 2008. "Skärskådad samling. Samiskt kulturarv i Nordiska museet."
In Christina Westergren \& Eva Silvén (eds.).

För Sápmi i tiden. Stockholm: Nordic Museum, 85-106. (Fataburen.)

Harrison, Rodney, Sarah Byrne \& Anne Clarke (eds.) 2013. Reassembling the Collection. Ethnographic Museums and Indigenous Agency. Santa Fe, NM: SAR Press.

Junka-Aikio, Laura 2019. "Institutionalization, neopoliticization and the politics of defining 'Sámi research." Acta Borealia 1, 1-22.

Kåks, Per 2000. "Repatriering av kulturhistoriska värdefulla föremål till ursprungliga ägarna." In Den samiska trumman i historisk tid och nutid. Rapport från seminarium vid Ájtte, Svenskt fjälloch samemuseum 15-16 juni 1999. Jokkmokk: Ájtte, 67-71.

Karp, Ivan \& Steven D. Lavine (eds.) 1991. Exhibiting Cultures. The Poetics and Politics of Museum Display. Washington, DC: Smithsonian Institution Press.

Keskitalo, Alf Isak 1994. Research as an Inter-ethnic Relation. Paper Delivered at the Seventh Meeting of Nordic Ethnographers Held at Tromsø Museum in Tromsø, Norway 29 August 1974. Rovaniemi: Arctic Centre, University of Lapland. (Dieđut 1994:7; Arktisen keskuksen tiedotteita 11.)

Kjellström, Rolf (ed.) 1974. Sameforskning $i$ dag och $i$ morgon. Stockholm: Nordic Museum.

Kopytoff, Igor 1986. "The cultural biography of things. Commoditization as process." In Arjan Appadurai (ed.). The Social Life of Things. Commodities in Cultural Perspective. Cambridge: Cambridge University Press, 64-91.

Korhonen, Olavi 2008. "Är lappologin död? Föredrag i samband med mottagandet av pris år 2002 från Stiftelsen språk och kultur, Umeå." Oknytt 3-4, 6-17.

Kuoljok, Kajsa 2010. "Att skildra en kultur." In Erland Mårald \& Christer Nordlund (eds.). Kamerajägaren. Stig Wessléns skildringar av naturen och det samiska. Umeå: Kungl. Skytteanska Samfundet, 189-202. 


\section{Eva SILVÉN}

116 Lantto, Patrik 2000. Tiden börjar på nytt. En analys av samernas etnopolitiska mobilisering $i$ Sverige 1900-1950. Umeå: Kulturgräns Norr.

Lantto, Patrik 2004. "Nationell symbol, etnisk markör eller utdöende näring? Bilden av renskötseln och dess betydelse inom samerörelsen i Sverige 1900-1960." In Patrik Lantto \& Peter Sköld (eds.). Befolkning och bosättning i norr. Etnicitet, identitet och gränser $i$ historiens sken. Umeå: Umeå University, 279-297.

Latour, Bruno 1992. "Technology is society made durable." In John Law (ed.). A Sociology of Monsters. Essays on Power, Technology and Domination. London: Routledge, 103-130.

Latour, Bruno 1998. "Kan vetenskapssociologi lära organisationsteori någonting?” In Artefaktens återkomst. Ett möte mellan organisationsteori och tingens sociologi. Stockholm: Nerenius \& Santérus, 269-289.

Latour, Bruno 2005. Reassembling the Social. An Introduction to Actor-Network-Theory. Oxford: Oxford University Press.

Lehtola, Veli-Pekka 2018. "Our histories in the photographs of the others. Sámi approaches to visual materials in archives." Journal of Aesthetics \& Culture 4, 1-13.

Lehtola, Veli-Pekka 2019. "Johan Nuorgam: Sámi Squanto and cultural broker." Nordisk Museologi 3, 77-95.

Lien, Sigrid \& Hilde Nielssen 2012. "Conventional ethnographic display or subversive aesthetics? Historical narratives of The Sami Museum, Riddo Duottar Museat-Sámiid VuorkáDávvirat (RDM-SVD) in Karasjok, Norway." In Dominique Poulot, José Maria Lanzarote Guiral \& Felicity Bodenstein (eds.). Great Narratives of the Past. Traditions and Revisions in National Museums. Conference Proceedings from EuNaMus, Paris July \& November 2011. Linköping: Linköping University Electronic Press, 599-615.

Lundmark, Lennart 2002. "Lappen är ombytlig, ostadig och obekväm..." Svenska statens samepolitik $i$ rasismens tidevarv. Umeå: Umeå University. Manker, Ernst 1956. Boken om Skum. Stockholm: LT. Manker, Ernst 1958. Rajd och karavan. Stockholm: LT. Manker, Ernst 1968. Skogslapparna i Sverige. Fältanteckningar. Stockholm: Almqvist \& Wiksell.

Manker, Ernst 1970. Åter mot norr. Minnesbilder och studier. Stockholm: LT.

Mathisen, Silje Opdahl 2010. "Likt men likevel forskjellig. Om representasjon av samisk identitet og forhistorie i samiske museer og majoritetsmuseer." In Bjarne Rogan \& Arne Bugge Amundsen (eds.). Samling og museum. Kapitler av museenes historie, praksis og ideologi. Oslo: Novus, 295-308.

Mathisen, Stein R. 2000. “Travels and narratives. Itinerant constructions of a homogenous Sami heritage." In Pertti Anttonen et al. (eds.). Folklore, Heritage Politics and Ethnic Diversity. A Festschrift for Barbro Klein. Tumba: Mångkulturellt Centrum, 179-205.

Mathisen, Stein R. 2004. "Representasjoner av kulturell forskjell. Fortelling, makt og autoritet i utstillinger av samisk kultur." Tidsskrift for kulturforskning 3, 5-26.

Medelius, Hans, Bengt Nyström \& Elisabet Stavenow-Hidemark (eds.) 1998. Nordiska museet under 125 år. Stockholm: Nordic Museum.

Mörkenstam, Ulf 1999. Om "Lapparnes privilegier". Föreställningar om samiskhet i svensk samepolitik 1883-1997. Stockholm: Stockholm University.

Olsen, Bjørnar 2000. "Bilder fra fortida? Representasjoner af samisk kultur i samiske museer." Nordisk Museologi 2, 13-30.

Peers, Laura \& Alison K. Brown (eds.) 2003. Museums and Source Communities. A Routledge Reader. London: Routledge.

Porsanger, Jelena 2004. "An essay about indigenous methodology." Nordlit 15, 105-120.

Pratt, Mary Louise 1991. "Arts of the contact zone." Profession, 33-40.

Pratt, Mary Louise 1992/2009. Imperial Eyes. Travel 


\section{SOCIOMATERIAL INTERTWINEMENTS IN SAMI RESEARCH}

Writing and Transculturation. 2nd ed. London \& New York: Routledge.

Pulkkinen, Risto 2005. "Lappology." In Ulla-Maija Kulonen, Irja Seurujärvi-Kari \& Risto Pulkkinen (eds.). The Saami. A Cultural Encyclopaedia. Vammala: SKS, 189-191.

Sandberg, Mark B. 2003. Living Pictures, Missing Persons. Mannequins, Museums, and Modernity. Princeton, NJ: Princeton University Press.

Silvén, Eva 2007. Sápmi - om att vara same i Sverige/ Sápmi - makkár lea leahkit sápmelaš Ruotas/ Sápmi - On Being Sami in Sweden. Stockholm: Nordic Museum. (Exhibition catalogue, with Mats Landin, illustrations \& Christina Westergren, coordination.)

Silvén, Eva 2009. "Lapps and Sami - narrative and display at the Nordiska Museet." In Kajsa Andersson (ed.). L'Image du Sápmi. Études comparées. Örebro: Örebro University, 74-91.

Silvén, Eva 2010. “Ernst Manker 1893-1972.” In Mats Hellspong \& Fredrik Skott (eds.). Svenska etnologer och folklorister. Uppsala: Kungl. Gustav Adolfs Akademien för svensk folkkultur, 135-141.

Silvén, Eva 2012. "Konstruktionen av ett samiskt kulturarv. Ernst Manker och den lapska ombudskåren." In Peter Sköld \& Krister Stoor (eds.). Långa perspektiv. Samisk forskning och traditionell kunskap. Umeå: Umeå University, 121-130.

Silvén, Eva 2014. "Constructing a Sami cultural heritage. Essence and emancipation." Ethnologia Scandinavica, 59-74.

Silvén, Eva 2015. “Genom kamerans öga. Ernst Manker som fotograf." In Kajsa Andersson (ed.). Sápmi i ord och bild. 1. Göteborg: On Line Förlag, 400-424.

Silvén, Eva 2016. "Hemfört, bortfört, återfört museerna och det samiska kulturarvet.” In Johan
Hegardt \& Trond Lundmo (eds.). Historiens hemvist. III. Minne, medier och materialitet. Göteborg/Stockholm: Makadam Förlag, 189-217. Silvén, Eva 2020. Friktion. Ernst Manker, Nordiska museet och konstruktionen av samiskt kulturarv. Stockholm: Nordic Museum. (Forthcoming.)

Sissons, Jeff 2005. First Peoples. Indigenous Cultures and their Futures. London: Reaktion.

Sleeper-Smith, Susan 2009. Contested Knowledge. Museums and Indigenous Perspectives. Lincoln, NV: University of Nebraska Press.

Smith, Laurajane 2006. Uses of Heritage. London: Routledge.

Smith, Linda Tuhiwai 1999/2006. Decolonizing Methodologies. Research and Indigenous Peoples. London: Zed Books.

Spivak, Gayatri Chakravorty 1985/1996. "Subaltern studies. Deconstructing historiography." In Donna Landry \& Gerald MacLean (eds.). The Spivak Reader. London: Routledge.

Thomasson Lars 1981. "Odugligförklara inte samerna." Samefolket 5, 17.

Westergren, Christina \& Eva Silvén (eds.) 2008. För Sápmi i tiden. Stockholm: Nordic Museum. (Fataburen.)

Xantaki, Alexandra, Sanna Valkonen, Leena Heinämäki \& Piia Kristiina Nuorgam (eds.) 2017. Indigenous Peoples' Cultural Heritage. Rights, Debates, Challenges. Leiden: Brill Nijhoff.

Eva Silvén, Ph.D.

mail@evasilven.se

Svampvägen 171

SE-122 63 Enskede, Sweden

nordiskamuseet.academia.edu/EvaSilven 